\title{
Bliskość i różnice tradycji chrześcijańskiego monastycyzmu Wschodu i Zachodu
}

Niniejszy tekst ma na celu zarysowanie szerokiego kontekstu jednego z aspektów dialogu między chrześcijańskim Wschodem a Zachodem. Kontekstem tym jest monastycyzm - zjawisko sytuujące się gdzieś na styku kultury i socjologii, materii i ducha. Jeśli chcemy mówić o monastycyzmie chrześcijańskim, nie możemy zapominać, że jest on znany także innym tradycjom duchowym - takim jak choćby hinduizm czy buddyzm. Monastycyzm jawi się więc jako naturalna płaszczyzna rozmaitych spotkań. Wśród tych przed chwilą wymienionych (kultura i socjologia, materia i duch) odnaleźć można i inne: spotkanie teraźniejszości i współczesności, dialog międzyreligijny czy wreszcie wspomniane spotkanie Wschodu z Zachodem.

Niniejsze słowa są jednocześnie próbą ogólnego zarysowania idei monastycyzmu tak, by mogła stać się ona naturalną przestrzenią dla tego spotkania ${ }^{2}$. W pewnym sensie ma ona znaczenie modelowe i kontekstu-

1 Bernard Sawicki, profes opactwa Benedyktynów w Tyńcu, od 2014 roku koordynator Instytutu Monastycznego na Wydziale Teologii Papieskiego Ateneum św. Anzelma w Rzymie. E-mail: bernard@benedyktyni.pl.

2 Określenia te stosujemy do szeroko rozumianej tradycji prawosławnej i katolickiej, jako że w tradycji protestanckiej zasadniczo monastycyzmu nie ma. Problem może pojawić się jednak wtedy, gdy Zachód skojarzymy z Kościołem rzymskokatolickim. Z jakim Kościołem wtedy kojarzyć Wschód? Wątpliwość tę rozwiewa twierdzenie samego św. Grzegorza Peradze: „We wszystkich Kościołach greckich monastycyzm przedstawia się w ten sam sposób, czy to w Gruzji, czy w Rosji, czy na Bałkanach..." Cytat (w przekładzie własnym) 
alne dla zrozumienia szeroko pojętego kulturowego spojrzenia na tożsamość kraju, w którym monastycyzm od wieków, a także do dzisiaj, jest bardzo obecny i pełni ważną rolę. Chodzi o Gruzję, rodzinny kraj cytowanego powyżej św. Grzegorz Peradze. To właśnie jego tekst, oryginalne i interesujące skądinąd porównanie mnicha wschodniego z mnichem zachodnim, jest inspiracją dla niniejszych rozważań ${ }^{3}$. W jakimś stopniu są one rozwinięciem jego intuicji ${ }^{4}$. A przy okazji warto przypomnieć związki tego gruzińskiego męczennika z Polską.

\section{Pojęcie monastycyzmu}

Na początku spróbujmy określić, czym jest monastycyzm. Niejest to zadanie łatwe - i, co wypada podkreślić, zarówno Wschód, jak i Zachód są tu zgodne. Obie tradycje na pewno mogłyby się podpisać pod określeniem starca Ignacego Briantchaninova, że „monastycyzm to wielka tajemnica

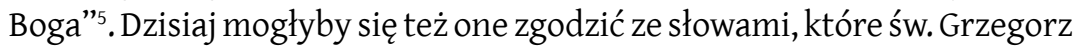
Peradze stosuje do mnicha Wschodu, określając go jako „postać rewolucyjną; jest on człowiekiem, który nieustannie zastanawia się nad najgłębszym sensem swojego ja i nad kresem ostatecznym. Człowiekiem, którego pragnienia i dążenia, i poznawanie rzeczy Boskich nie będzie nigdy miało końca... Dąży on jedynie do stania się człowiekiem «doskonałym», człowiekiem, który wyszedł z rąk Bożych w raju i który wyjdzie odnowiony z ręki Chrystusa na końcu czasów”" Warto wspomnieć, że podobnie rozumiał monastycyzm oryginalny jego teoretyk zachodni, przedwcześnie zmarły profesor benedyktyńskiego Ateneum św. Anzelma w Rzymie,

\footnotetext{
za recenzją z pracy św. G. Peradze, Der Christliche Orient zatytułowanej Le moine oriental, „Irénikon” (1936), s. 473.

3 Odnosimy się tu do jego pracy przytoczonej w poprzednim przypisie.

4 Przy okazji warto przypomnieć związki tego gruzińskiego archimandryty i męczennika z Polską: w roku 1933 był w Krakowie, gdzie skatalogował rękopisy gruzińskie Biblioteki Czartoryskich, a w latach 1933-1939 wykładał na Uniwersytecie Warszawskim. Zginął w Auschwitz w roku 1942 (J. Charkiewicz, Męczennicy XX wieku. Martyrologia prawosławia $w$ Polsce w biografiach świętych, Warszawa 2008, s. 161-172).

5 C. Lialine, Le „Mystére monastique”, cz. 1, „Irénikon” 69 (1996) 3, s. 332.

6 Le moine oriental, dz. cyt., s. 473.
} 
mnich benedyktyńskiego opactwa w Gerleve, o. Anzelm Stolz, który był prekursorem współczesnego pojmowania monastycyzmu na Zachodzie. Co ciekawe, zbliżał się w tym do wschodniego rozumienia monastycyzmu?

W europejskiej perspektywie genezy monastycyzmu dopatrzeć się można już w nauce Platona i w pewnych jej wątkach podjętych przez Filona z Aleksandrii czy Epikteta ${ }^{8}$, aczkolwiek nieobce były mu wpływy judeochrześcijańskie. Od tradycyjnej religijności greckiej odróżniała go powściągliwość w mistyce, rozumianej jako owoc ascezy, co wyglądało zupełnie inaczej w przypadku ekstaz greckich, którą to tradycję podjął z kolei Plotyn'. Jak to ujął jeden z badaczy obu tradycji monastycznych, „, w monastycyzmie istnieje pewne dążenie do życia krańcowo intensywnego, tak pod względem fizycznym, jak i intelektualnym", które można określić jako „najpełniejsze życie” czy „entuzjazm”10. Jest to życie chrześcijańskie, które ma swe organiczne i być może tajemnicze prawa, a za cel wyłącznie swą intensywność. Patrząc na monastycyzm sumarycznie, wymienić by można następujące jego archetypy, wspólne dla tradycji Wschodu i Zachodu:

a) idea ewangelicznego naśladowania Chrystusa (sequela Christi);

b) tęsknota za ideałem życia pierwszej wspólnoty chrześcijan z Dziejów Apostolskich;

c) przygotowanie do męczeństwa (preparatio ad martyrium);

d) walka z demonami;

e) wygnanie (Exodus);

f) naśladowanie życia aniołów;

g) powrót do rajskiej niewinności;

h) czuwanie (czujność);

i) „prawdziwa filozofia"11.

C. Lialine, Le „Mystére monastique”, cz. 1, dz. cyt., s. 333.

8 A. Guillaumont, U źródeł monastycyzmu chrześcijańskiego (tłum. s. Scholastyki Wirpszanki OSBap z oryginału: Études sur la spiritualité de l'Orient chrétien, Abbaye de Bellefontaine 1996), t. 1, Kraków 2006, s. 83-86.

9 A. Guillaumont, U źródeł monastycyzmu chrześcijańskiego, dz. cyt., s. 189-190; 203-204).

10 C. Lialine, Monachisme oriental et monachisme occidental, „Irénikon” 33 (1960) 4, s. 435$459,436$.

11 Por. P. Miquel, Narodziny i rozwój monastycyzmu chrześcijańskiego, w: A. Solignac i in., Monastycyzm. Historia i duchowość, Kraków 2002 (tłum. D. Stanickiej-Apostoł oryginału Le monachisme. Histoire et spiritualité, Paris 1980). 
Jak widać, archetypy te są wątkami biblijnymi, swoistymi duchowymi topoi, bardzo znaczącymi w tradycji judeochrześcijańskiej. Choć ich wykaz ma zaledwie charakter sygnalny, pozwala jednak właściwie ogarnąć szerokie tło rzeczywistości monastycznej.

\section{Wspólny korzeń - przestrzenie spotkania}

Nie można zapominać, iż - jak to przyjmuje większość znawców tematu, aczkolwiek nie zawsze bez kontestacji - monastycyzm wyrasta z jednego korzenia, mianowicie monastycyzmu egipskiego. Ten powstały na przełomie III i IV wieku szeroki ruch religijny szybko zaczął się rozprzestrzeniać - najpierw na Palestynę i Syrię (i dalej na inne kraje Azji), a wkrótce też na Europę. I choć - z punktu widzenia geograficznego i historycznego - już od IV wieku mówimy o monastycyzmie wschodnim i zachodnim, ów wspomniany powyżej wspólny korzeń pozostaje w świadomości monastycznej praktycznie aż do dzisiaj. Widoczne jest to zwłaszcza w dziejach i wpływach niektórych ważnych postaci początków monastycyzmu, najpełniej przejawiających się poprzez migrację tekstów. Ikoną łączności monastycyzmu wschodniego z zachodnim jest Jan Kasjan, wykształcony tak w kulturze łacińskiej, jak i greckiej. Mieszkał on początkowo w Egipcie i Bizancjum, by potem przeszczepiać ideał monastycyzmu do Rzymu i Galii. Jest autorem podstawowych tekstów dla tradycji monastycznej: Institutiones i Collationes. Warto wspomnieć, że od tytułu tego ostatniego dzieła, przedstawiającego nauki mnichów egipskich, a czytanego w klasztorach podczas wieczornego posiłku, wywodzi się polskie słowo „kolacja”. Sam św. Benedykt w swojej Regule odwołuje się do tekstów Kasjana oraz św. Bazylego ${ }^{12}$, którego Regułe znał w łacińskim przekładzie Rufina z Akwilei. W pewnym sensie Reguła św. Benedykta jest syntezą tradycji wschodniej i zachodniej. Obok wpływów św. Bazylego wyraźne są w niej wpływy powstałej w środowisku

12 Św. Benedykt z Nursji, Reguła, Św. Grzegorz Wielki, Dialogi. Księga Druga, przekł. A. Świderkówna, Kraków 1994, 73, 5. 
zachodnim tzw. Reguły Mistrza ${ }^{13}$. W połowie VIII wieku papież Zachariasz dokonał przekładu pierwszej biografii św. Benedykta, Dialogów autorstwa papieża Grzegorza Wielkiego, na język grecki. Przekład ten cieszył się sporym powodzeniem ${ }^{14}$. Od IX wieku istnieje śpiewane do dzisiaj oficjum bizantyńskie ku czci św. Benedykta, który - ponieważ żył przed podziałem Kościoła na wschodni i zachodni, jest czczony w obu tradycjach monastycznych ${ }^{15}$. Od X do XIII wieku na górze Athos działał klasztor benedyktyński Apothikon-Amalfion, ufundowany przez mnichów z Benewentu, a potem zarządzany przez benedyktynów z księstwa Amalfion. W XX wieku górę Athos co jakiś czas odwiedzają benedyktyni ${ }^{16}$. Monastyczna tradycja wschodnia przenika wszakże i na Zachód. Klasztory tej tradycji istnieją także w Europie Zachodniej, czego przykładem jest włoski monaster w Grottaferrata ${ }^{17}$. Szeroki odbiór w monastycznej tradycji zachodniej znajdują też wschodnie teksty. Poza wspomnianymi powyżej ich wpływami na Regułe św. Benedykta, emblematyczny wydaje się tu Żywot Warłaama i Jozafata, przypisywany św. Janowi Damasceńskiemu, a wywodzący się najprawdopodobniej z tradycji manichejskiej i buddyjskiej (VII/VIII wiek), zapisanej po persku, następnie zaś przetłumaczonej na arabski, z którego powstała z kolei pierwsza wersja chrześcijańska tej historii zanotowana w języku gruzińskim! Do Europy Zachodniej tekst ten trafił w XI wieku - najpierw po łacinie, by następnie pojawić się w języku starofrancuskim, włoskim,

13 Por. J. Leroy, San Benedetto nel mondo bizantino, w: Schola Christi. 50 anni dell'Istituto Monastico di Sant'Anselmo, a cura di M. Bielawski, A. Schmidt, Roma 2002, s. 511-525 (Studia Anselmiana).

14 J. Leroy, San Benedetto nel mondo bizantino, dz. cyt., s. 512-516.

15 Autorami tekstów liturgii wschodniej o św. Benedykcie są Nil z Rossano (910-1004) oraz Józef Hymnograf (816-886). Więcej na ten temat można przeczytać w: M. Nin, San Benedetto e l'Oriente cristiano. Proteggi Montecassino e tutti noi che ti cantiamo, „L'Osservatore Romano" 22-23.05.2009, http://w2.vatican.va/content/osservatore-romano/it/comments/2009/documents/117q01b1.html (18.12.2017).

16 A. Lambrechts, Pèlerins bénédictins au Mont Athos, „Irénikon” 71 (1998) 2-3, s. 281-289; więcej na ten tmat można znaleźć w: M. Merlini, Un monastero benedettino sul Monte Athos XXIII secolo, Subiaco 2017.

17 S. Parenti, Il monastero Italo-bizantino di Grottaferrata la Chiesa di Roma nell'XI secolo, w: Il monachesimo tra eredità e aperture, a cura di M. Bielawski, D. Hombergen, Roma 2004, 347-366 (Studia Anselmiana). 
portugalskim, prowansalskim, irlandzkim, niemieckim, angielskim, niderlandzkim, norweskim i szwedzkim ${ }^{18}$. Jest to wymowny przykład nie tylko życia w obu tradycjach samego tego tekstu, ale i roli, którą niekiedy odgrywała w tym Gruzja. Innym przykładem tekstu wschodniego, który wywarł znaczący wpływ na tradycję zachodnią, są pisma Izaaka z Niniwy (VII wiek). Powstałe w języku syryjskim, zostały przełożone na grekę w klasztorze Św. Saby na Pustyni Judzkiej, gdzie w końcu IX wieku powstały wersja gruzińska i arabska. W XIII wieku powstała wersja łacińska, wiek potem pojawiły się przekłady na języki słowiańskie. W roku 1909 z języka rosyjskiego pisma Izaaka z Niniwy zostały przetłumaczone na japoński. Obecnie są dostępne w językach europejskich. Notabene jest to jedyny syryjski autor wspomniany przez Katechizm Kościoła katolickiego z roku 1992 (nr 2717) ${ }^{19}$. Są to tylko dwa, ale jakże znaczące przykłady rzeczywistego istnienia wspólnego korzenia, z którego wyrastają tradycje wschodnia i zachodnia - zarówno ta monastyczna, jak i duchowa.

Podsumowując wspólne początki obu monastycyzmów, wypada stwierdzić, że w IV wieku, czyli w swoich początkach, monastycyzm zachodni był, jak to ujmuje Pericoli Ridolfini, całkowicie „importowany” ze Wschodu, niemal dokładnie i z pełną świadomością „kalkując” model wschodni. Niewielkie różnice usprawiedliwiał jedynie aspekt geograficzny. Z czasem zaznacza się też odrębność w podejściu do pracy. Z racji swego pochodzenia społecznego mnisi zachodni nie musieli (przynajmniej w takim stopniu jak ich wschodni współbracia) pracować na utrzymanie. Autorzy tekstów monastycznych, w tym Kasjan, Augustyn, Benedykt, troskliwie przypominali jednak ten właściwy dla Wschodu ideał utrzymywania się z własnej pracy ${ }^{20}$.

18 M. Van Parys, Sapienter indocti. Moines et culture dans l'Europe latine, „Irénikon” 70 (1997), s. 328-330.

19 S. P. Brock, Crossing the Boundaries: An Ecumenical Role Played By Syriac Monastic Literatur, w: Il monachesimo tra eredità e aperture, dz. cyt., s. 222-224.

20 F. S. Pericoli Ridolfini, Monachesimo „orientale” e „occidentale”: criteri e limiti della distinzione nel periodo delle origini, w: Il monachesimo occidentale dalle origini alla Regula Magistri, Roma 1998, s. 43-44 (Studia Ephemeridis Augistinianum, 62). 


\section{Różnice}

Powyższe, raczej jedynie szkicowo zarysowane płaszczyzny wspólne pozwalają lepiej ukazać obecne w obu tradycjach różnice. I tym razem prześledzimy je sygnalnie, wychodząc od wspólnie stosowanych pojęć. Blisko pół wieku temu cytowany już przez nas jeden z autorów, ujął je następująco:

a) Na Wschodzie monastycyzm jest czymś istotnym dla Kościoła. Na Zachodzie jest on w Kościele ważny, ale nie niezbędny.

b) Duchowość monastycyzmu wschodniego jest bardziej oczywista, ascetyczna czy subiektywna, związana z kontemplacją i pozaintelektualna. Na Zachodzie jest ona dyskretna i ma charakter „obiektywny”, bardziej związany z wiernością codziennemu, zrównoważonemu życiu wspólnotowemu, a wyrasta z Biblii i ze studium ${ }^{21}$.

Święty Grzegorz Peradze różnicę tę uzależnia od różnych elementów konstytuujących życie monastyczne obu tradycjach. Na Wschodzie jest to osobowość przełożonego (mistrza). Na Zachodzie - reguły i struktury organizacyjne. Mnich wschodni jest mistykiem o osobowości poetyckiej. Mnich zachodni - uczonym, specjalistą w swej branży ${ }^{22}$. Spróbujmy to rozwinąć i uszczegółowić.

Najpierw uczyńmy to w kluczu antropologicznym. Dla obu Tradycji ważne i bliskie jest pojęcie serca. Wschód rozumie je bardziej biblijnie, jako siedlisko całego życia duchowego człowieka, wielką rolę przyznając he zy chazmowi, czyli specjalnej postawie modlitewno-ascetycznej, która ma wieść bezpośrednio do pokoju serca, co zarazem oznacza przebóstwienie człowieka. Praktyka ta powstała w XIII wieku, znajdując swój najpełniejszy wyraz w pismach Grzegorza Palamasa $(† 1359)^{23}$. Zachód tymczasem postrzega serce bardziej w aspekcie „fizjologicznym” czy też psychologicznym, widząc w nim siedlisko uczuć, nierzadko tych najbardziej tajemniczych.

${ }^{21}$ C. Lialine, Monachisme oriental et monachisme occidental, dz. cyt., s. 456-457.

22 Le moine oriental, dz. cyt., s. 474.

23 M. Bielawski, Monastycyzm bizantyński, w: A. Solignac i in., Monastycyzm. Historia i duchowość, dz. cyt., s. 244-246. 
Wspominamy to rozumienie pojęcia „serce”, gdyż z niego wynika rozumienie modlitwy. Jej nieustanne sprawowanie jest niewątpliwie wspólną troską Wschodu i Zachodu. Ten pierwszy jednak postrzega modlitwę integralnie, w duchu wspomnianego hezychazmu - jako modlitwę całego serca prowadzącą ku symfonii wspólnoty i pojmowaną całościowo jako synteza mistycznego piękna i doktrynalnej głębi liturgii ${ }^{24}$. Jest to zarazem modlitwa całkowicie angażująca, przyjmująca zazwyczaj formę medytacji opartej na powtarzaniu pewnych formuł. Tego typu praktykę modlitwy i jej kontekst teologiczny, ale i egzystencjalny, najpełniej wyrażają Filokalia ${ }^{25}$. W jej centrum jest „modlitwa Jezusowa”, będąca wschodnim odpowiednikiem zachodniego różańca. Właściwa takiej postawie nieustanna pamięć o Bogu jest tematem zachowanego po gruzińsku listu Arseniusza ${ }^{27}$. Na Zachodzie modlitwa jest rozumiana w sposób bardziej złożony. Doświadczenie serca w pewnym sensie oddziela się od rozumu. Rozwój teologii spekulatywnej uczynił ją z czasem bardziej dyscypliną uniwersytecką niż bezpośrednim wyrazem i świadectwem wiary. W ten sposób modlitwa zachodnia łatwiej zaczęła skłaniać się ku rozmaitym skodyfikowanym formom, niekoniecznie bezpośrednio wyrażającym doktrynę lub z niej wynikającym, gdy tymczasem na Wschodzie taki związek jest czymś naturalnym. Jedną z modlitewnych praktyk Zachodu, wywodzących się ze środowiska monastycznego i łączących element kultu z lekturą tekstu, jest praktyka „Bożego czytania”, zwana lectio divina. Jednakże z biegiem czasu, niekoniecznie w związku z nią, wykształcają się na Zachodzie całkiem odrębne szkoły duchowe, proponujące rozmaite „drogi modlitwy”.

Rozumienie i praktykowanie modlitwy jest pośrednio owocem różnych filozofii stojących w tle obu monastycyzmów. Monastycyzmowi wschodniemu bliskie są systemy starożytnego Wschodu, niekiedy ocierające się

24 M. Van Parys, Jeden ze wszystkimi, Kraków 2010, s. 140-141 (tłum. K. Kubieniec, S. Jankowskiej oryginału Uno con tutti. Essere monaci oggi, Magnano 2008).

25 E. Behr-Sigel, Monastycyzm rosyjski, w: A. Solignac i in., Monastycyzm. Historia i duchowość, dz. cyt., s. 163.

26 Wywodzi się ona z klasycznego tekstu Opowieści pielgrzyma w polskim przekładzie M. Cyrulskiego, Kraków 2011.

27 Opowieści pielgrzyma, dz. cyt., s. 70. 
o swoisty ekstremizm, czego przykładem byli znani w monastycyzmie syryjskim, a potem rosyjskim „szaleńcy dla Chrystusa” ${ }^{28}$, w Rosji zwani „jurodiwymi”29. Zachodowi bliższy był platonizm, unikający materializacji czy lokalizacji aktów życia duchowego ${ }^{30}$. Tym, co bez wątpienia łączyło obie tradycje, było pojmowanie monastycyzmu jako życia oddzielonego od świata i rezygnacja z oficjalnej aktywności społecznej na korzyść kontemplacji. Wschód zawsze był wierny „teoretycznemu”, kontemplacyjnemu wymiarowi monastycyzmu ${ }^{31}$. Zachował on pod tym względem jedność, gdy tymczasem na Zachodzie przemiany cywilizacyjne (gospodarcze i społeczne) XII i XIII wieku doprowadziły do fragmentaryzacji i specjalizacji życia monastycznego ${ }^{32}$. Tak powstały zakony „niemonastyczne”, które podjęły się dzieł o wyraźnym profilu społecznym, dostosowując do tego praktykę własnej duchowości. Inne rozumienie wspólnotowości Wschodu i Zachodu było wszakże obecne już w łonie tradycji monastycznej. Chodzi tu na przykład o podejście do wspólnej własności rozumianej w duchu ideału z Dziejów Apostolskich, gdzie czytamy: „Jeden duch i jedno serce ożywiały wszystkich wierzących. Żaden nie nazywał swoim tego, co posiadał, ale wszystko mieli wspólne. [...] Nikt z nich nie cierpiał niedostatku, bo właściciele pól albo domów sprzedawali je i przynosili pieniądze [uzyskane] ze sprzedaży, i składali je u stóp Apostołów. Każdemu też rozdzielano według potrzeby" (Dz 4, 32-33.35). Święty Benedykt wraz ze św. Augustynem (ale i za św. Bazylim!) podkreślali wagę wspólnej własności. Tymczasem nie było to wcale oczywiste choćby w monastycyzmie palestyńskim ${ }^{33}$. Można zaryzykować stwierdzenie, że monastycyzm Zachodni cechowało żywsze poczucie wspólnotowości, jak i większy uniwersalizm. Mnisi wschodni bardziej cenili odrębność swych wspólnot. Każda z nich silniej niż na Zachodzie wiązała

\footnotetext{
28 A. Guillaumont, U źródeł monastycyzmu chrześcijańskiego, dz. cyt., t. 2, s. 80, 135-136.

29 Praktyka ta opisana jest np. w pozycji C.Wodziński, Święty Idiota, Gdańsk 2000.

30 A. Guillaumont, U źródeł monastycyzmu chrześcijańskiego, dz. cyt., t. 2, s. 79.

31 M. Van Parys, Jeden ze wszystkimi, dz. cyt., s. 22.

32 A. Mainardi, Monachesimo occidental e monachesimo orientale: quale scambio di doni?, w: Il monachesimo tra eredità e aperture, dz. cyt., s. 886.

33 E. Lanne, Saint Benoît et le monachisme oriental de son temps, w: Il monachesimo tra eredità e aperture, dz. cyt., s. 696-697.
} 
się z hierarchią kościelną. W pewnym sensie przekłada się to na rozumienie i przeżywanie autorytetu. Na Wschodzie istnieje większa świadomość ojcostwa duchowego ${ }^{34}$, silniejsza - klasyczna skądinąd dla tradycji mniszej - więź mistrz-uczeń. Trzeba tu wspomnieć tradycję „starców”, będących swoistym „archetypem mnicha”, którzy swego czasu wywarli w Rosji wielki wpływ choćby na takich pisarzy jak Leontiew, Gogol, Dostojewski czy Sołowiew ${ }^{35}$. Monastycyzm zachodni będzie miał natomiast bardziej charakter systemowy i poniekąd demokratyczny.

\section{Bliskość}

Ukazawszy wspólne korzenie monastycznych tradycji Wschodu i Zachodu, a następnie, wraz z upływem wieków i ze zmianą okoliczności, stopniowe ich różnicowanie, wypada pokazać aktualną wspólną perspektywę obu tradycji. Nie bez znaczenia będzie tu kontekst współczesności, z którą każda na swój sposób - obie jednak w pewnym sensie solidarnie - się konfrontuje. Zarazem jest to zwrócenie uwagi na sporo paralelizmów, które nie od dzisiaj funkcjonowały w dziejach każdej z tradycji, potwierdzając ich pochodzenie z jednego źródła. Zacznijmy od silnej i cieszącej się sporym autorytetem idei cenobityzmu - więc klasztorów wspólnotowych. W obu tradycjach właśnie jej monastycyzm zawdzięczał swą ważną rolę cywilizacyjną. Na Zachodzie było to dzieło reformy św. Benedykta z Anianu (†821), który - popierany przez Karolingów - rozszerzył na cały świat łaciński ideały św. Benedykta z Nursji. Analogiczną rolę w Bizancjum odegrał - zresztą mniej więcej w tym samym czasie św. Teodor Studyta (†826). Warto w tym miejscu wspomnieć, że również

34 M. Van Parys, Jeden ze wszystkimi, dz. cyt., s. 109-111.

35 E. Behr-Sigel, Monastycyzm rosyjski, dz. cyt., s. 166-167. Przykładem takiego oddziaływania był klasztor Optina w Kozielsku, przeżywający rozkwit w połowie XIX wieku, co przedstawia A. Mainardi, La riforma possibile. Società e monachesimo in Russia nel XIX secolo: il fenomeno dello „starčestvo”, w: Church, Society and Monasticism. Acts of the International symposium Rome, May 31 - June 3, 2006, eds. E. López-Tello García, B. S. Zorzi, Roma 2009 (Studia Anselmiana 146, Analecta Monastica 9). Warto dodać, że w latach 1939-1940 w murach tego klasztoru przetrzymywano polskich oficerów przed rozstrzelaniem ich w Katyniu. 
monastycyzm gruziński, zachowując całą swoją oryginalność, rozwijał i umacniał się dzięki powstawaniu licznych klasztorów cenobitycznych, czego inspiratorem był Grzegorz z Chanzia $(† 860)^{36}$.

Być może należałoby tu mówić o pewnym powinowactwie charyzmatycznym, które poprzez wieki rozwoju obu tradycji było wyraźnie odczuwalne. Wspomniani reformatorzy życia monastycznego promujący cenobityzm nie są jego jedynym przykładem. Niewielki odstęp czasu dzielił biografie św. Saby (*439) i św. Benedykta (*480) z Nursji. Ich przebieg jest w sposób znamienny paralelny. Obaj święci zostali „wyciągnięci" ze swoich pustelni przez dołączających do nich pasterzy i okolicznych pustelników stając się założycielami cenobium. Obaj przewidzieli czas swojej śmierci, stając się po niej bohaterami biografii spisanej przez ich uczniów - Cyryla ze Scytopolis w przypadku św. Saby i św. Grzegorza Wielkiego w przypadku św. Benedykta ${ }^{37}$. W obrębie obu tradycji istniały też świadome, obustronne inspiracje. Reformator kamedułów, Paolo Giustiniani na początku XVI wieku odbył długą podróż na Wschód, gdzie zapoznał się tamtejszym życiem eremickim. W tym samym mniej więcej czasie Maksym Grek został dominikaninem w klasztorze Girolama Savonaroli we Florencji, po czym - potępiony przez tego ostatniego - został mnichem na górze Athos ${ }^{38}$. Wspominaliśmy już o szerokiej cyrkulacji w obu tradycjach tych samych tekstów. Warto wspomnieć, że dzieło św. Piotra Damianiego De vita solitaria jest przytoczone w biografii św. Serafina z Sarowa ${ }^{39}$. Wydaje się, że to wzajemne przenikanie się myśli ascetycznej i teologicznej nie było wszakże nigdy tak intensywne jak w dzisiejszych czasach.

W obu tradycjach klasztor jest miejscem szczególnym - znakiem społeczności i czasów, w których żyje. Najważniejsze - by nie rzec: źródłowe - ośrodki monastyczne były usytuowane na górach, niejednokrotnie do dzisiaj pozostając świadkami rzeczywistości coraz bardziej odmiennej niż otaczający nas świat. Tak jest w przypadku najbardziej znaczących

\footnotetext{
M. Bielawski, Monastycyzm bizantyński, dz. cyt., s. 240.

E. Lanne, Saint Benoit et le monachisme..., dz. cyt., s. 692.

A. Mainardi, La riforma possibile..., dz. cyt., s. 884.

A. Mainardi, La riforma possibile..., dz. cyt., s. 885.
} 
ośrodków monastycznych Wschodu (góra Athos, góra Olimp), jak i Zachodu (Subiaco, Monte Cassino).

Jednakże, chociaż klasztory spełniają swoją tajemniczą rolę w świecie poprzez wierne trwanie i promieniowanie tam, gdzie powstały, nie można zapominać o wielkiej roli ewangelizacyjnej, jaką odegrały w obu tradycjach. Do rangi symbolu urasta tu monastycyzm iroszkocki. Istnieje tradycja wywodząca go ze Wschodu. Jeśli dodamy do tego aktywną działalność misyjną mnichów z Zielonej Wyspy w Europie, monastycyzm jawi się jako ruch par excellence ewangelizacyjny. Nieco później, ale z większym rozmachem i systematycznością, zaangażował mnichów w ewangelizację św. Grzegorz Wielki (†604). W konsekwencji chrześcijaństwo zagościło w Europie dzięki mnichom, z których wymieńmy choćby św. Brunona z Kwerfurtu, św. Wojciecha czy św. Oskara. Mnisi również tworzyli zręb struktur kościelnych i nieśli cywilizację łacińską na tereny krajów, które przyjęły chrzest. Podobnie było na Wschodzie. Choć Apostołowie Słowian, św. Cyryl i Metody nie byli mnichami misjonarzami, po chrzcie Rusi w roku 988 ich dzieło kontynuowali mnisi pochodzenia bizantyńsko-bułgarskiego. W celu wzmocnienia pogłębienia wiary chrześcijańskiej na przełomie tysiącleci powstaje Ławra Pieczar Kijowskich, pierwszy klasztor na terenie Rusi ${ }^{40}$. Mnisi wschodni będą odtąd silnie angażować się w życie Kościoła, w jego misję społeczną i w jego reformy. Tak działo się w przypadku św. Nila Sorskiego czy św. Józefa z Wołokołamska ${ }^{41}$. Jeśli pamiętamy, że w Kościele wschodnim hierarchia wywodzi się z kręgów monastycznych, łatwo zrozumieć fundamentalną rolę monastycyzmu w tamtejszej tradycji. Zresztą już od początków monastycyzmu mnisi nie pozostawali obojętni na toczące się nieraz bardzo gwałtowne debaty na tematy doktrynalne, w konsekwencji angażując się niekiedy dość znacznie nie tylko w synody czy sobory, lecz nawet i w politykę. Pod tym względem Zachód, z powodu wyraźnego oddzielenia mnichów od hierarchii, zasadniczo pozostaje na uboczu tego typu rozgrywek. Wspomnieliśmy jednak zaangażowanie zachodnich mnichów w tworzenie struktur kościelnych i administracyjnych Europy. W okresie szczyto-

40 E. Behr-Sigel, Monastycyzm rosyjski, dz. cyt., s. 151-152.

${ }^{41}$ E. Behr-Sigel, Monastycyzm rosyjski, dz. cyt., s. 159 -161. 
wego rozwoju monastycyzmu zachodniego (X-XII wiek) opactwo Cluny i cystersi wywierali wpływ na całą chrześcijańską Europę, co w rezultacie, paradoksalnie, doprowadziło do kryzysu życia monastycznego. Jak wspomniał Odo Casel - duchowy entuzjazm monastycyzmu, monastycyzm może być skutecznie zagrożony przez jego instytucjonalizację, czy wręcz sakramentalizację ${ }^{42}$. Formy instytucjonalne, klerykalne i kanoniczne mogą zagrażać duchowi „tajemnicy” monastycyzmu, sprawiając, że oderwie się od chrześcijaństwa i eklezjologii w stronę subiektywizmu i ascetyzmu ${ }^{43}$. Utrzymanie złotego środka wydaje się tyle konieczne, ile trudne.

W tym sensie monastycyzm jest świadkiem napięcia, które niesie ze sobą każda próba życia według ideałów. Jest to szczególnie aktualne w naszych czasach. Tak, jak monastycyzm pragnie i może być tu solidarny z całym światem, jeszcze bardziej naturalne wydaje się pragnienie takiej solidarności we wzajemnym odniesieniu do siebie wschodniej i zachodniej tradycji monastycznych. Tym ważniejsze i pilniejsze wydaje się uświadomienie sobie ewentualnych pól współdziałania w celu wiarygodnego i jak najskuteczniejszego przekazania światu niezmiernych bogactw obu tradycji monastycznych.

Z licznych, coraz bardziej zagospodarowanych obszarów takiego współdziałania wymieńmy kilka. Antidotum na współczesny kryzys autorytetu może być obecna w obu tradycjach idea „ojcostwa duchowego”. Klasztory obu tradycji już są - ale przecież mogą być jeszcze bardziej miejscem gościnności, pomocy, szacunku i formacji, a także świadectwem wartości i nadziei. Nie bez znaczenia jest również pełnienie przez nich roli strażników i promotorów kultury, rozumianej jako ślad tradycji i dziedzictwo ducha związane z chrześcijańskim dziedzictwem Europy ${ }^{44}$. W tych obszarach bezwarunkowo spotykają się obie tradycje, połączone jedną troską ${ }^{45}$. Dialog w przestrzeni kultury chrześcijańskiego (i mona-

42 C. Lialine, Le „Mystére monastique ”, cz. 1, dz. cyt., s. 340-341.

43 C. Lialine, Le „Mystére monastique”, cz. 2, „Irénikon” 69 (1996) 4, s. 496.

${ }_{44}$ M. Van Parys, Jeden ze wszystkimi, dz. cyt., s. 12-13, 96.

45 Jak ujął to E. Lanne: „Dzisiaj jak wczoraj, walka o ten wspólny ideał mnichów Wschodu i Zachodu, niezależnie od odległości w czasie, kulturze czy nawet eklezjologii, stwarza między nimi niezapomniane braterstwo". E. Lanne, Saint Benoît et le monachisme..., dz. cyt., s. 699. 
stycznego) Wschodu i Zachodu rozwija się coraz intensywniej. Wystarczy wspomnieć recepcję twórczości filmowej Andrieja Tarkowskiego w Europie Zachodniej czy choćby prace polskich konserwatorów przy Srebrnych Wrotach w Kijowie. Cieszą inicjatywy tworzenia stałych forów takiego dialogu, których początek wiąże się właśnie ze środowiskami monastycznymi, takimi jak Chevetogne, Gerleve czy Bose. Jest to praktyczna forma ważnego aspektu relacji dialogicznej, którą Jan Paweł II

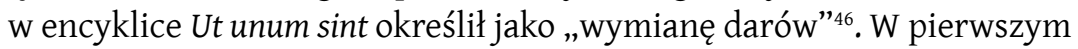
rzędzie i, jak to pokazaliśmy, od wielu wieków, niejako naturalnie dotyczy to modlitwy i treści duchowej ${ }^{47}$. Pośrednio wynika z tego możliwość pewnej solidarności i wsparcia, gdy chodzi o formację adeptów do życia mniszego. Jest ona szczególnie potrzebna nie tylko ze względu na sytuację duchową współczesnej cywilizacji, lecz także z uwagi na fakt, że obecnie następującemu po okresie represji komunistycznych wzrostowi liczby klasztorów i mnichów w Europie Wschodniej towarzyszy wymieranie większości monastycznych klasztorów Europy ${ }^{48}$. Może jest to jeszcze jedna, najbardziej aktualna z tych różnic obu tradycji, które paradoksalnie mogą doprowadzić do bliskości.

46 Jest to nr 57 tejże encykliki.

47 M. Van Parys, Jeden ze wszystkimi, dz. cyt., s. 81.

48 A. Mainardi, La riforma possibile..., dz. cyt., s. 888. 


\section{Summary}

\section{Bliskość i różnice tradycji chrześcijańskiego monastycyzmu} Wschodu i Zachodu

Jedną z ważniejszych przestrzeni dialogu ekumenicznego między Kościołami Wschodu i Zachodu jest monastycyzm. Mimo wspólnych korzeni jego formy i znaczenie w Kościele różnią się na Wschodzie i Zachodzie. Różnice te dotyczą w większości roli przełożonego, instytucjonalnych aspektów życia i relacji z władzami kościelnymi. Stała wymiana tekstów i inspiracji zawsze była świadectwem nieustannego dialogu między dwiema tradycjami tego samego stylu życia. Dzisiaj wspólne wartości, współdzielone przez mnichów wschodnich i zachodnich, takie jak „duchowe ojcostwo”, kultura i wychowanie, mogą okazać się pomocne nie tylko w dialogu ekumenicznym, lecz i w procesie ewangelizacji.

Słowa kluczowe: monastycyzm, Kościół wschodni, Kościół zachodni, dialog ekumeniczny

\section{Closeness and Differences in the Tradition of Christian Monasticism} of the East and the West

One of the important platforms of the ecumenical dialogue between Eastern and Western Churches is monasticism. Despite common roots, its forms and meaning in the Church is different in the West and in the East. These differences concern mostly the role of superior, the institutional aspects of life and reference to the Church authorities. The constant exchange of texts and inspirations has always been a sign of permanent dialogue between two traditions of the same style of life. Today, the common values shared by the monks both in the West and the East, such like "spiritual fatherhood", culture and education may become helpful not only for the ecumenical dialogue but also in the process of evangelization.

Keywords: monasticism, Eastern Church, Western Church, ecumenical dialogue

\section{Bibliografia}

[Brak autora] „Le moine oriental”, „Irénikon” 13 (1936) 4, s. 473-474.

Behr-Sigel E., Monastycyzm rosyjski, w: A. Solignac i in., Monastycyzm. Historia i duchowość, Kraków 2002 (tłum. D. Stanickiej-Apostoł oryginału Le monachisme. Histoire et spiritualité, Paris 1980), s. 150-171.

Bielawski M., Monastycyzm bizantyński, w: A. Solignac i in., Monastycyzm. Historia $i$ duchowość, Kraków 2002 (tłum. D. Stanickiej-Apostoł oryginału Le monachisme. Histoire et spiritualité, Paris 1980), s. 229-247. 
Brock S. P., Crossing the Boundaries: An Ecumenical Role Played By Syriac Monastic Literatur, w: Il monachesimo tra eredità e aperture, a cura di M. Bielawski, D. Hombergen, Roma 2004, s. 222-224 (Studia Anselmiana).

Charkiewicz J., Męczennicy XX wieku. Martyrologia prawosławia w Polsce w biografiach świętych, Warszawa 2008.

Guillaumont A., U źródeł monastycyzmu chrześcijańskiego (tłum. s. Scholastyki Wirpszanki OSBap z oryginału: Études sur la spiritualité de l'Orient chrétien, Abbaye de Bellefontaine 1996), t. 1, Kraków 2006.

Gribomont J., Narodziny i rozwój monastycyzmu chrześcijańskiego, w: A. Solignac i in., Monastycyzm. Historia i duchowość, Kraków 2002 (tłum. D. Stanickiej-Apostoł oryginału Le monachisme. Histoire et spiritualité, Paris 1980), s. 45-65.

Lambrechts A., Pèlerins bénédictins au Mont Athos, „Irénikon” 71 (1998) 2-3, s. 281-289.

Lanne E., Saint Benoît et le monachisme oriental de son temps, w: Il monachesimo tra eredità e aperture, a cura di M. Bielawski, D. Hombergen, Roma 2004 (Studia Anselmiana), s. 691-699.

Leroy J., San Benedetto nel mondo bizantino, w: Schola Christi. 50 anni dell'Istituto Monastico di Sant'Anselmo, a cura di M. Bielawski, A. Schmidt, Roma 2002 (Studia Anselmiana), s. 511-525.

Lialine C., Le „Mystére monastique”, cz. 1, „Irénikon” 69 (1996) 3, s. 332-346.

Lialine C., Le „Mystére monastique”, cz. 2, „Irénikon” 69 (1996) 4, s. 477-497.

Lialine L., Monachisme oriental et monachisme occidental, „Irénikon” 33 (1960) 4, s. 435-459.

Mainardi A., La riforma possibile. Società e monachesimo in Russia nel XIX secolo: il fenomeno dello „starčestvo”, w: Church, Society and Monasticism. Acts of the International Symposium Rome, May 31 - June 3, 2006, eds. E. López-Tello García, B. S. Zorzi, Roma 2009 (Studia Anselmiana 146, Analecta Monastica 9), s. 509-529.

Mainardi A., Monachesimo occidental e monachesimo orientale: quale scambio di doni?, w: Il monachesimo tra eredità e aperturę, a cura di M. Bielawski, D. Hombergen, Roma 2004 (Studia Anselmiana)

Merlini M., Un monastero benedettino sul Monte Athos X-XIII secolo, Subiaco 2017.

Nin M., San Benedetto e l'Oriente cristiano. Proteggi Montecassino e tutti noi che ti cantiamo, „L'Osservatore Romano” 22-23.05.2009, http://w2.vatican.va/content/osservatore-romano/it/ /2009/documents/117q01b1.html (18.12.2017).

Parenti S., Il comments monastero Italo-bizantino di Grottaferrata la Chies a di Roma nell'XI secolo, w: Il monachesimo tra eredità e aperturę, a cura di M. Bielawski, D. Hombergen, Roma 2004 (Studia Anselmiana), s. 347-366.

Pericoli Ridolfini F. S., Monachesimo „orientale” e „occidentale”: criteri e limiti della distinzione nel periodo delle origini, w: Il monachesimo occidentale dalle origini alla Regula Magistri, Roma 1998, s. 37-44 (Studia Ephemeridis Augistinianum, 62).

Van Parys M., Jeden ze wszystkimi, Kraków 2010 (tłum. K. Kubieniec i S. Jankowskiej oryginału Uno con tutti. Essere monaci oggi, Magnano 2008).

Van Parys M., Sapienter indocti. Moines et culture dans l'Europe latine, „Irénikon” 70 (1997), s. 315-333.

Wodziński C., Święty Idiota, Gdańsk 2000. 